\title{
マグネシウムの製錬／溶解・鋳造 Smelting/alloying/casting of magnesium
}

\author{
伊藤 茂* \\ Tsutomu ITO*
}

\section{1. マグネシウムの資源 ${ }^{1)}$}

マグネシウム $(\mathrm{Mg})$ は，地球上で 8 番目に豊富な元素で あり, 地殼の約 $2.5 \%$ を占める。また海水中には $\mathrm{Mg}$ 元素と して約 $0.13 \%$ 溶解して抢り, 800 トンの海水から約 1 トンの $\mathrm{Mg}$ が採れる。わが国ではドロマイトが豊富に産出し, 栃木 県, 岐阜県が鉱石産地として著名で, 約 20 年前まで熱還元 法によるマグネシウム製錬の原料として使用された。表 1 に $\mathrm{Mg}$ を含有する主な資源の組成と $\mathrm{Mg}$ 含有率を示す。

\section{1 マグネシウムの製鍊と加工工程}

$\mathrm{Mg}$ は大別すると熱還元法と電解法の 2 つ方法によって 製造されており, 純 $M g$ は主にアルミニウム用合金添加剤, 鉄鋼の脱硫剂などに利用され, また $\mathrm{Mg}$ の合金地金は各種成
形加工品として利用されている。図 1 に $\mathrm{Mg}$ の製鍊から加工 までのフローシートを示す。全世界における Mg 需要量（2007 年）は約 86 万 $\mathrm{t} /$ 年であるが，その $75 \%$ は中国に扔ける熱還 元法（ピジョン法）によって供給されている。

\section{2 溶融塩電解法 ${ }^{2)}$}

塩化マグネシウム $\left(\mathrm{MgCl}_{2}\right)$ を含有する混合溶融塩 $\left(\mathrm{MgCl}_{2}-\mathrm{NaCl}-\mathrm{KCl}-\mathrm{CaCl}_{2}\right)$ を電気分解することによって, 鉄陰 極に溶融 $\mathrm{Mg}$ が，黒鉛陽極に塩素ガス $\left(\mathrm{Cl}_{2}\right)$ が得られる。一 般に電解法は熱還元法に比べて工場の生産規模が大きく, $3 \sim 6$ 万 $\mathrm{t} /$ 年以上である。主原料の塩化マグネシウム $\left(\mathrm{MgCl}_{2}\right)$ は, 主に次の 3 種類の形態のあのが利用されており, 実用化 企業名とともに示す。な拉, チタンの製錬工場において塩化 チタンの還元剂として Mg を利用している場合は, 副生物と

表 $1 \mathrm{Mg}$ の資源と $\mathrm{Mg}$ 含有率

\begin{tabular}{|c|c|c|c|c|}
\hline 名称 & 組成 & 色 / 光沢 & 比重 & $\mathrm{Mg} \%$ \\
\hline 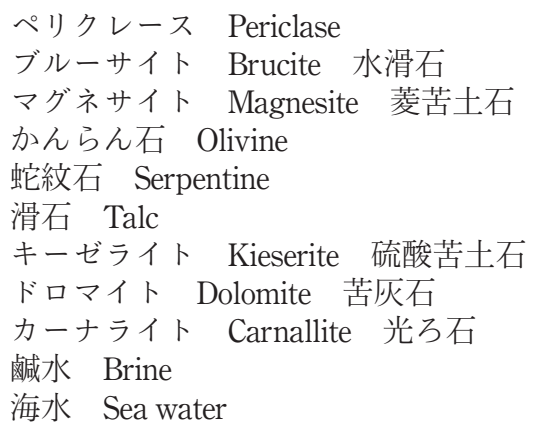 & $\begin{array}{l}\mathrm{MgO} \\
\mathrm{Mg}(\mathrm{OH})_{2} \\
\mathrm{MgCO}_{3} \\
(\mathrm{MgFe}) \mathrm{SiO}_{4} \\
3 \mathrm{MgO} \cdot 2 \mathrm{SiO}_{2} \cdot 2 \mathrm{H}_{2} \mathrm{O} \\
3 \mathrm{MgO} \cdot 4 \mathrm{SiO}_{2} \cdot \mathrm{H}_{2} \mathrm{O} \\
\mathrm{MgSO}_{4} \cdot \mathrm{H}_{2} \mathrm{O} \\
\mathrm{MgCO}_{3} \cdot \mathrm{CaCO}_{3} \\
\mathrm{MgCl}_{2} \cdot \mathrm{KCl} \cdot 6 \mathrm{H}_{2} \mathrm{O} \\
\mathrm{NaCl} \cdot \mathrm{KCl} \cdot \mathrm{MgCl}_{2} \text { などの溶液 } \\
\mathrm{NaCl} \cdot \mathrm{KCl} \cdot \mathrm{MgCl}_{2} \text { などの溶液 }\end{array}$ & $\begin{array}{l}\text { 白/真珠 } \\
\text { 白/真珠 } \\
\text { 白/絹 } \\
\text { 褐色/ガラス } \\
\text { 黒緑/半透明 } \\
\text { 皇/真珠 } \\
\text { 無·白/半透明 } \\
\text { 白/真珠 } \\
\text { 無/乳白色 } \\
\quad \text { - } \\
\quad \text { - }\end{array}$ & $\begin{array}{l}3.6 \\
2.4 \\
3.0 \\
3.6 \\
2.6 \\
2.7 \\
2.6 \\
2.9 \\
1.6 \\
- \\
1.03\end{array}$ & $\begin{array}{c}60 \\
41 \\
28 \\
28 \\
26 \\
23 \\
17 \\
13 \\
9 \\
0.7 \sim 4 \\
0.13\end{array}$ \\
\hline
\end{tabular}

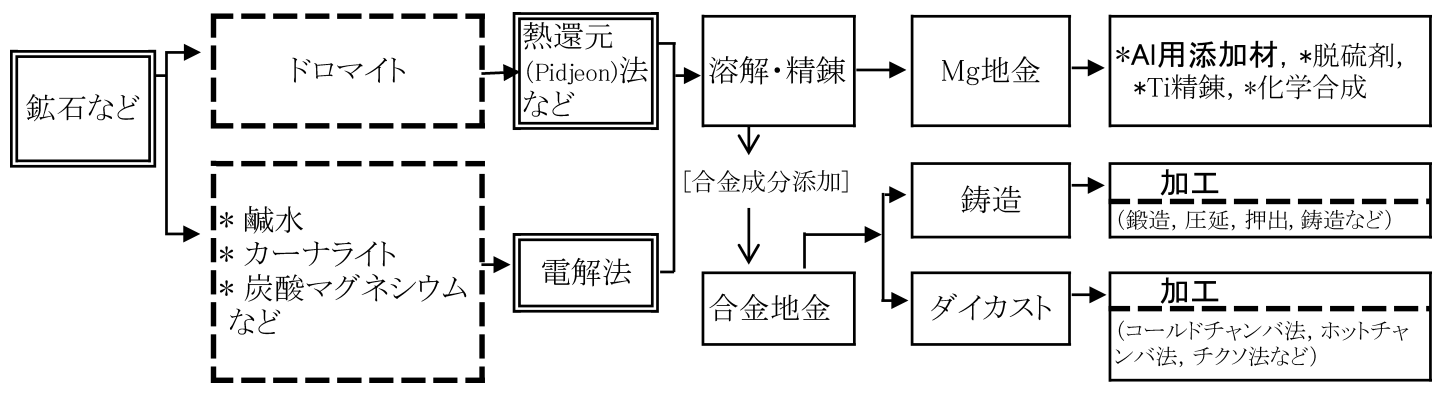

図 1 マグネシウムの原料から加工品までのフローシート

*伊藤技術士事務所（广 328-0024 栃木県栃木市樋八口町 130-40)。ITO Professional Engineering Office (130-40 Hinokuchi-cho, Tochigi-shi, Tochigi 328-0024).

受付日：平成 21 年 4 月 13 日 受理日：平成 21 年 6 月 4 日 


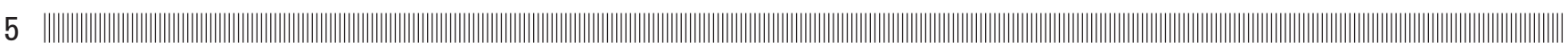

して無水塩化マグネシウムが生成するので, 電解法により $\mathrm{Mg}$ を内製している。

（1）部分含水の塩化マグネシウムを原料とする方法：

$\mathrm{MgCl}_{2} \cdot 1.25 \mathrm{H}_{2} \mathrm{O}$ (Dow Chemical, USA)

(2) 高純度無水塩化マグネシウムを原料とする方法：溶融 $\mathrm{MgCl}_{2}$ で酸化マグネシウム $\mathrm{MgO}$ が $0.05 \%$ 以下の原料 (US-Magnesium (USA) ; Norsk Hydro (Norway \& Canada); Noranda (Canada)) ; 国内, 海外のチタン製錬工場

（3）カーナライトを原料とする方法：溶融 $\mathrm{MgCl}_{2} \cdot \mathrm{KCl}$ (Dead Sea Magnesium（Israel）；Solikamsk（Russia）；民和マグネシウ 厶 (中国) )

\section{2 .1 電解法の特徽}

$\mathrm{Mg}$ 電解法は非常に高度な塩素コントロール技術が求めら れるので, 総合化学会社が実施している場合が多い。特に無 水塩化マグネシウムを製造するための高温での塩化反応技術 および電解炉から発生する塩素の回収・漏机防止技術は有毒 ガスの取扱いという公害対策が重要である。無水塩化マグネ シゥム製造技術について，現在稼働している US-Magnesium 社の工程を図 2 に示すが，主な特徵を挙げると以下の通りで ある。

（1）ブライン（畧水）中に含まれる $\mathrm{Mg}$ と塩素含有率を高 める（元の $\mathrm{Mg}$ 濃度は $0.42 \%$ であるが，商業生産上必要とさ れる濃度は $8.5 \%$ 以上）ことが必要であり, 工場近くの Great Salt Lake の場合 3 か所の蒸発用塩田がある。

（2）予熱器, スプレードライヤにより濃縮・脱水し, 粉末 状の $92 \%$ 品位 $\mathrm{MgCl}_{2}$ を製造するが，この段階で水分はおよ そ $5 \%, \mathrm{MgO}$ が $3 \%$ 残留している。

（3）残留水分, $\mathrm{MgO}$ 並びに不純物（臭素, 硫酸塩, アル ミニゥムと重金属の塩類）を除去するために煉瓦張り槽内で 電熱溶融し, カーボンと塩素を導入する。さらに溶融 $\mathrm{MgCl}_{2}$ を反応槽に移送，塩化反応により $\mathrm{MgO}$ を $0.05 \%$ 以下に制御

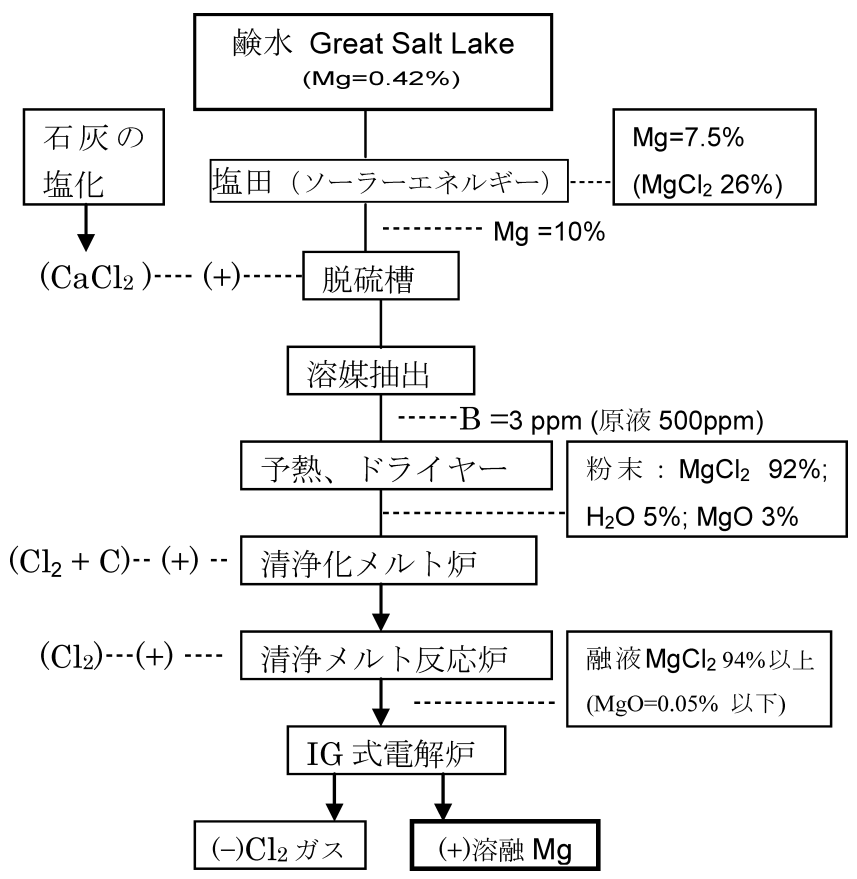

図 2 US-Magnesium 社の無水塩化マグネシゥムの製造工程
して電解浴に供給する。

（4）電解条件は, 浴温度 $650 \sim 710^{\circ} \mathrm{C}$, 電圧 $4.5 \sim 6.0 \mathrm{~V}$, 電流 効率 10 12kWh/kg-Mg である。

\section{3 熱還元法 ${ }^{3)}$}

現在, 中国に扔いて大量に生産されている $\mathrm{Mg}$ の製造方法 はけい素還元法で，発明者の名前をとってピジョン（Pidgeon） 法之呼ばれている。国内では独自技術により 1956 年に古河 マグネシウム（栃木県小山市）抢よび 1966 年に宇部興産（山 口県宇部市）によって同法が実用化されたが, 現在は同事業 から撤退した。中国のピジョン法による $\mathrm{Mg}$ 生産は日本の技 術指導によってスタートしたが, 現在, 中国独自のプロセス 改良が進行中のようである。原料ドロマイト $\left(\mathrm{MgCO}_{3} \cdot \mathrm{CaCO}_{3}\right)$ を約 $1100 \sim 1300^{\circ} \mathrm{C}$ で焼成して得られるドライム $(\mathrm{MgO} \cdot \mathrm{CaO})$ と， $75 \%$ 以上のシリコンを含有するフェロシリコン $(\mathrm{Fe}-\mathrm{Si})$ の粉末を混合後, 団鉱にする。水平タイプの耐熱反応管 （Retort）内に装填 $し$, 温度約 $1200^{\circ} \mathrm{C}$, 真空度 $1.3 \mathrm{~Pa}(0.01$ Torr）に扑て反応させると, $\mathrm{Mg}$ 蒸気が低温部（380 520 $\left.0^{\circ} \mathrm{C}\right)$ に結晶状に凝縮し王冠状固体（クラウン）として得られる。 焼成㧍よび真空還元の反応式を示す。

（1）ドロマイトの焼成反応：

$$
\mathrm{MgCO}_{3} \cdot \mathrm{CaCO}_{3} \rightarrow \mathrm{MgO} \cdot \mathrm{CaO}+2 \mathrm{CO}_{2}
$$

（2）焼成ドロマイトとフェロシリコンとの還元反応：

$$
2(\mathrm{MgO} \cdot \mathrm{CaO})+\mathrm{Si} \rightarrow 2 \mathrm{Mg}+2 \mathrm{CaO} \cdot \mathrm{SiO}_{2}
$$

1.3.1 ピジョン法の特徵

（1）ドロマイト中の不純物 $\mathrm{SiO}_{2}, \mathrm{Fe}_{2} \mathrm{O}_{3}, \mathrm{Al}_{2} \mathrm{O}_{3}$ は, 焼成に よって得られるドライム $(\mathrm{MgO} \cdot \mathrm{CaO})$ の反応性を低下させ る。 $\mathrm{Na}_{2} \mathrm{O}, \mathrm{K}_{2} \mathrm{O}$ などのアルカリ分は $\mathrm{Mg}$ と同様に還元されて 凝縮し, $\mathrm{Mg}$ 結晶の取扱い中に着火, 酸化口スの原因となる

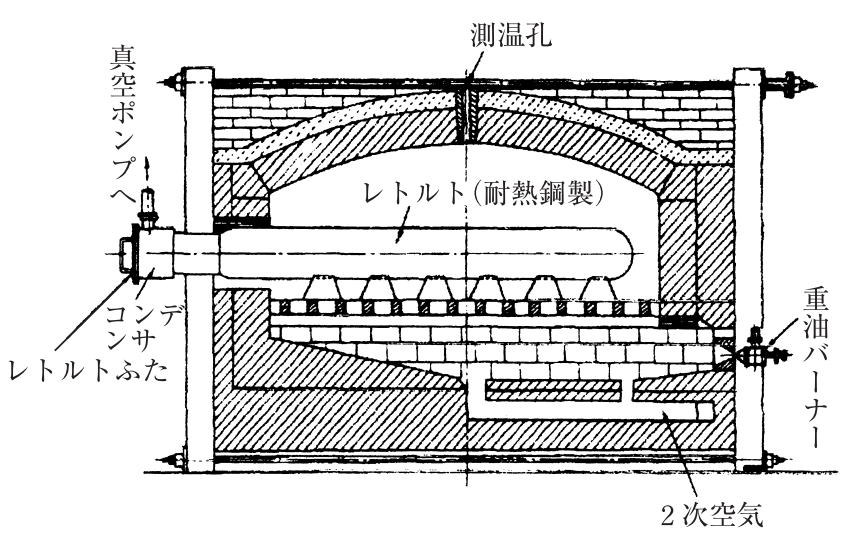

図 3 ピジョン法の熱還元炉

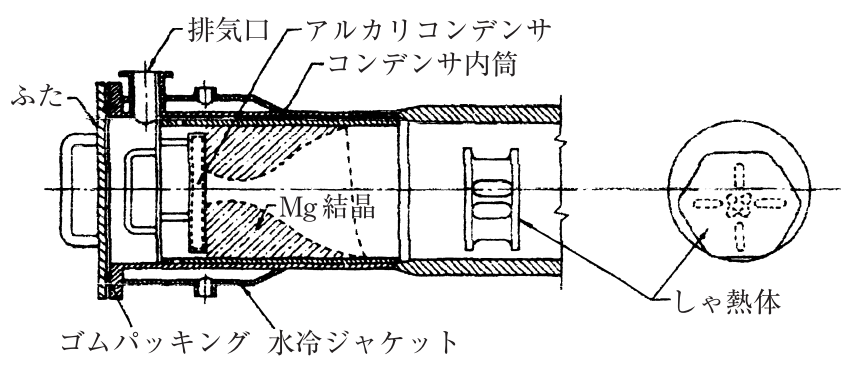

図4 マグネシウムの凝縮部 


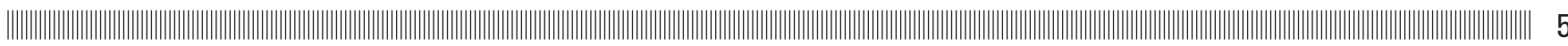

表 $2 \mathrm{Mg}$ 地金品位

\begin{tabular}{|c|c|c|c|c|c|c|c|c|c|}
\hline 製法 & $\mathrm{Al}$ & $\mathrm{Cu}$ & $\mathrm{Fe}$ & $\mathrm{Mn}$ & $\mathrm{Si}$ & $\mathrm{Ni}$ & $\mathrm{Zn}$ & その他分析元素 & $\mathrm{Mg}$ \\
\hline $\begin{array}{l}\text { ピショョン法 } \\
\text { ピション法 } \\
\text { 電解法 DSMg 代表分析値 } \\
\text { 電解法 DSMg low Fe } \\
\text { 電解法 DSMg 高純度 } 99.96\end{array}$ & $\begin{array}{l}0.003 \\
0.003 \\
0.01 \\
0.005 \\
0.001\end{array}$ & $\begin{array}{l}0.001 \\
0.001 \\
0.001 \\
0.0005 \\
0.0003\end{array}$ & $\begin{array}{l}0.0018 \\
0.0016 \\
0.03 \\
0.006 \\
0.03\end{array}$ & $\begin{array}{l}0.003 \\
0.003 \\
0.005 \\
0.003 \\
0.002\end{array}$ & $\begin{array}{l}0.015 \\
0.005 \\
0.003 \\
0.0005 \\
0.001\end{array}$ & $\begin{array}{l}0.0010 \\
0.0010 \\
0.001 \\
0.001 \\
0.0003\end{array}$ & $\begin{array}{r}0.008 \\
0.005 \\
0.001 \\
0.0005 \\
<0.0010\end{array}$ & $\begin{array}{l}\mathrm{Pb}, \mathrm{Sn}, \mathrm{Ca}, \mathrm{Ti}, \mathrm{Zr} \\
\mathrm{Pb}, \mathrm{Sn}, \mathrm{Na}, \mathrm{Ca}, \mathrm{Ti} \\
\mathrm{Pb}, \mathrm{Sn}, \mathrm{Na}, \mathrm{Ti}, \mathrm{P}, \mathrm{N}\end{array}$ & $\begin{array}{l}99.96 \\
99.98 \\
99.80 \\
99.95 \\
99.96\end{array}$ \\
\hline
\end{tabular}

ので，鉱石品位の確認が重要である。

（2）還元剂のフェロシリコン価格は製造コストに占める割 合が最む大きい。 $\mathrm{Si}$ 含有率が $75 \%$ 以下の品位の場合，還元 反応の収率を低下させる。

（3）反応レトルトは遠心鋳造された $28 \mathrm{Cr}-15 \mathrm{Ni}$ などの耐熱 鋼が使用され，耐久寿命数（240 270日）は製造コストに影 響する。

（4）装入原料約 $200 \mathrm{~kg}$ 当たり 12 時間サイクルでの $\mathrm{Mg}$ 収 量は約 $34 \mathrm{~kg}$ である。装入原料約 $430 \mathrm{~kg}$ での長期操業試験結 果によると, 24 時間サイクルで約 $75 \mathrm{~kg}$ の $\mathrm{Mg}$ 収量である。

（5）バッチ操業であるため，人件費の負担が大きい。中国 での人件費は最近アップしており, 安い人件費のメリットが 低下し始めている。

（6）電解法に比べピジョン法は技術的に単純であるため事 業化しやすい。生産規模む一工場当たり, 数百トンから 1 万 トンレベルで生産可能である。設備費は電解法の 15,000 ドル/ $\mathrm{t}-\mathrm{Mg}$ に対して 1,200-1,500 ドル/t- $\mathrm{Mg}$ と 1/10 である。

（7）中国では公害対策（防塵，石炭燃焼による排ガス, SOxなど）が強化され, 同時に原材料の高騰, 人件費対策, 高効率の生産技術開発, 競争力のある供給安定性が課題之 なっている。

図 3 にピジョン法の熱還元炉, 図 4 にマグネシウムメタル の凝縮部を示す。

\section{4 マグネシウム地金の品質}

表 2 にピジョン法および電解法による $\mathrm{Mg}$ 地金の分析值の 例を示す。ピジョン法による $\mathrm{Mg}$ は電解法による地金に較べ, 純度が高い。電解法では電極に鉄を使用するため $\mathrm{Mg}$ 地金中 への Fe の混入量が増える。一般に Fe 含有量はピジョン法地 金の 10 倍多い。ただし, 現在, 電解法による高純度 $\mathrm{Mg}$ 規 格品屯提供されており，デッドシーマグネシウム社 (D.S.Mg) の最近の分析例を載せた。

\section{2. 構造材用途のマグネシウム合金 ${ }^{4)}$}

$\mathrm{Mg}$ は合金化することによってその強度，鋳造性，成形性 などが改善される。合金は構造材として利用が進められ，特 に一体成形, 軽量化, 薄肉化の要望の強い需要分野での利用 促進が期待されている。国内における $\mathrm{Mg}$ 合金の用途は，自 動車などの輸送関連部品, ノートパソコン, 携帯電話, デジ カメなどの情報電子関連部品や光学機器, あるいはチェーン ソウなどのアウトドア用品, 自転車関連部品などがある。 2007 年における国内の構造材用途（12,000t/年）の内 $81 \%$ は ダイカスト， $9 \%$ はチクソ成形である。その他， Mg 合金の圧 延・押出材への利用, あるいは重力鋳造分野における消費が
表 $3 \mathrm{Mg}$ 合金種とその代表的組成例

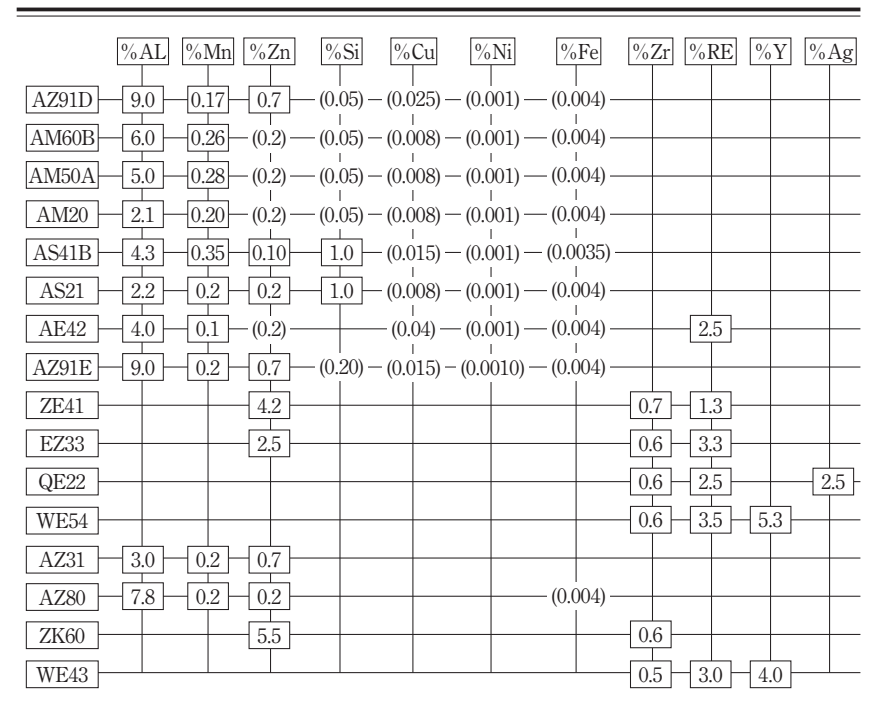

: 成分の平均値, ( ) : 不純物規制値

10\%である。

表 3 に各種 $M g$ 合金とその代表的組成例を示す。

2.1 合金成分の効果 ${ }^{1), 5)}$

構造材用 $\mathrm{Mg}$ 合金は, ダイカスト，砂型・金型鋳造，押 出，圧延材などの形で使用される。目標の材料特性を得るた めに，各種合金成分が添加される。添加元素之主な効果につ いて示す。

・[強度, 鋳造性の改良]：アルミニウム $(\mathrm{Al})$, 亜鉛 $(\mathrm{Zn})$

・[耐食性の向上]：マンガン (Mn)

- [耐熱強度の向上] : 希土類と重希土類 $(\mathrm{RE}=$ ミッシュメ タル $(\mathrm{MM})$, ランタン $(\mathrm{La})$, セリウム $(\mathrm{Ce})$, プラセ オジウム $(\mathrm{Pr})$, ネオジゥム $(\mathrm{Nd})$, ガドリニウム $(\mathrm{Gd})$ など）,イットリウム（Y)，アルカリ土類（カルシウム $(\mathrm{Ca})$, ストロンチウム $(\mathrm{Sr}))$, 銀 $(\mathrm{Ag})$, けい素 $(\mathrm{Si})$

・[結晶微細化 $]$ ：ジルコニウム $(\mathrm{Zr})$, ただし, $\mathrm{Al}$ 含有合金 では結晶を粗大化する。

・[酸化防止効果 $]$ ：ベリリウム $(\mathrm{Be})$, カルシウム $(\mathrm{Ca})$

・[脱 $\mathrm{Fe}$ 効果］：マンガン ( $\mathrm{Mn})$, ジルコニウム ( $\mathrm{Zr}$ ) 次の成分は耐食性, 延性を低下させるため抑制すべき元素 である。

・[耐食性の阻害] : ニッケル $(\mathrm{Ni})$, 鉄 $(\mathrm{Fe})$, 銅 $(\mathrm{Cu})$, コ バルト $(\mathrm{Co})$

・[延性の阻害］：ナトリウム $(\mathrm{Na})$, カリウム $(\mathrm{K})$, バリウ 么 $(\mathrm{Ba})$ 


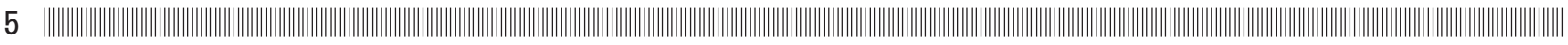

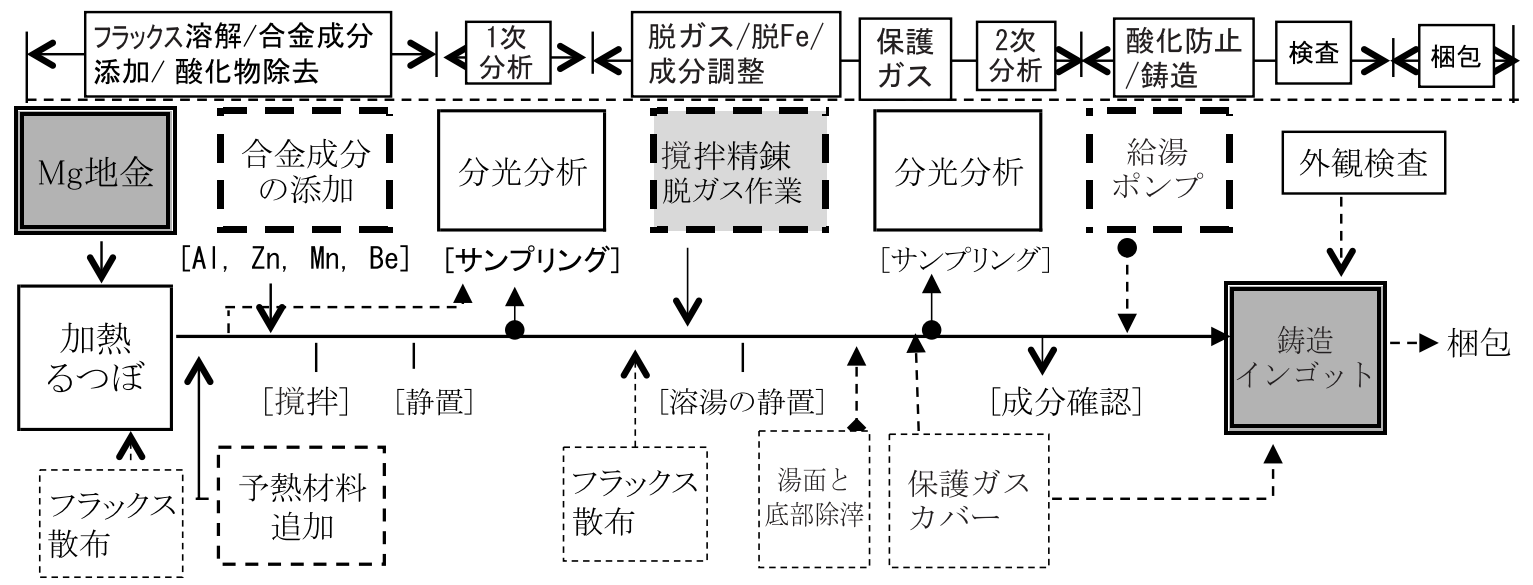

図 5 マグネシウム合金の製造工程

なお，合金種の表示法は ASTM 規格による場合が一般的で あり，代表合金成分元素の表示例は以下の通りである。

$\mathrm{A}=\mathrm{Al}, \mathrm{Z}=\mathrm{Zn}, \mathrm{M}=\mathrm{Mn}, \mathrm{S}=\mathrm{Si}, \mathrm{R}=\mathrm{RE}, \mathrm{E}=\mathrm{MM}, \mathrm{W}=\mathrm{Y}, \mathrm{Q}=\mathrm{Ag}$, $\mathrm{J}=\mathrm{Sr}, \mathrm{X}=\mathrm{Ca}, \mathrm{K}=\mathrm{Zr}, \mathrm{C}=\mathrm{Cu}, \mathrm{P}=\mathrm{Pb}, \mathrm{H}=\mathrm{Th}$

図 5 に $\mathrm{Mg}$ 合金の製造工程の一例を示す。

\section{3. マグネシウムおよび合金の溶解設備}

マグネシウムの溶解に使用される設備は多くの場合，鉄鋼 材料が使用されている。一方で，Mg の耐食性に影響を及ぼ す成分 $(\mathrm{Fe}, \mathrm{Cu}, \mathrm{Ni})$ が $\mathrm{Mg}$ 溶湯中に混入しないよう留意が必 要である。

（1）溶解炉：国内，米国ではガス加熱炉が，多く利用され ており, 高い溶解速度が得られ生産性に優れている。炉温の 制御を容易にするために上下 2 段のバーナを使用している例 あある。炉には排気ガス用煙突を取付ける。ヨーロッパでは 炉温の均一化，制御が容易な，電気抵抗加熱炉が主流であ る。溶解炉の上部には，るつぼからの排ガスを吸引する可動 式フードが取付けられ，ガス中和塔に接続されている。

（2）るつぼ：マグネシウムおよび合金溶解用るつぼは， Ni を含有しないクロム鋼の圧延材または低炭素鋼圧延材の溶接 構造体を使用する。国内では溶融アルミニウムめっき処理 （アルミニウム溶湯中に浸漬後熱処理し，鋼に拡散させる方 法）により耐酸化性を改善したるつぼが使用されている。る つぼの肉厚は溶解重量によって変わるが, 目安としては 10 50 kg，300 500 kg および 1500 2000 kg 重量の場合，そ れぞれ 5 10 mm，20 30 mm，25 40 mm 付近である。

バーナ加熱の場合，炎の当たる位置が偏らないように，炉 内でのるつぼ設置位置を定期的に変える。るつぼフランジ部 は後述する酸化防止の観点から，るつぼ蓋との密着性を確保 するために，変形防止用リブ付け，炉体との間に断熱材の設 置, などに配慮する。るつぼの使用履歴と検査記録を管理 し, 廃棄基準を定めておく。

（3）るつぼ蓋：るつぼ蓋は $1500 \mathrm{~kg}$ 重量の場合，板厚 $10 \mathrm{~mm}$ 以上でフランジ付構造が一般的であり, 変形防止のた めにリブ補強をする。蓋には溶湯の精鍊・擋拌作業が行いや すいように，比較的大きい精錬作業ドアと注湯作業用ドアが あり，その他保護ガス導入および熱電対セットポートなどが

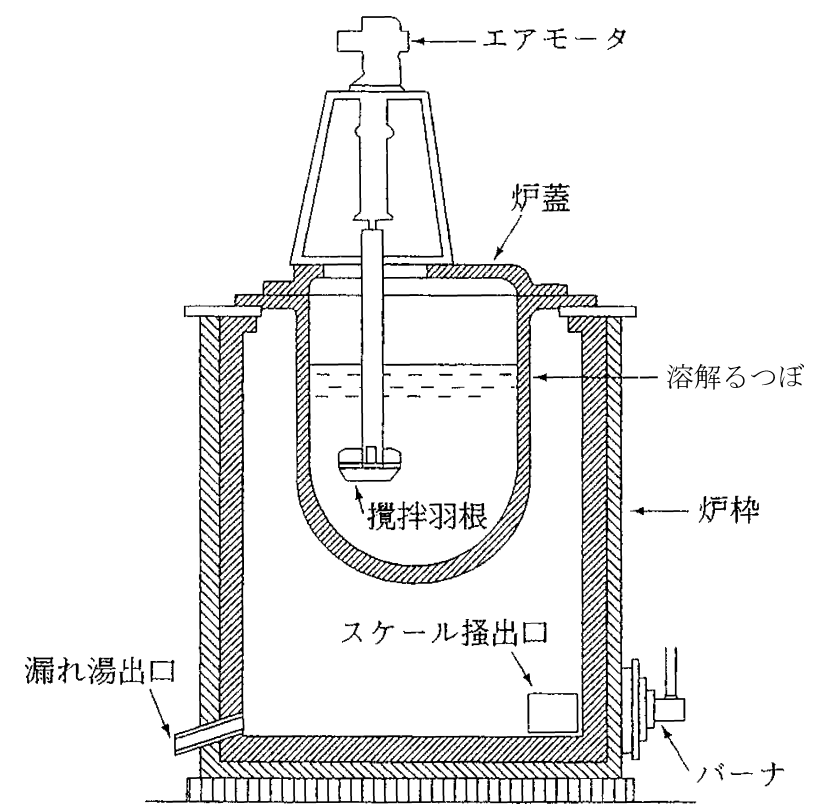

図 6 溶解るつぼと擋拌機設置の概要

作業しやすい位置に配置されている。精錬作業ドアは「材料 の装填」,「フラックス散布」,「るつぼ内の除滓作業」,「傾斜 型擋拌機の装入」などの作業口として利用され, 注湯作業ド アは「メタル移送管の装着または汲出し作業」口として利用 される。その他外気の侵入防止のため, 例えばるつぼフラン ジと蓋との合せ部には断熱性ガスケットを使用する。

（4）温度計：熱電対を炉内と溶湯内にセットし, 安全管理 並びにプロセス管理上のデー夕を記録する。

（5）撹找機：精錬工程では回転速度が 60 300 rpm の回転 子から非常に微細なガス泡を分散噴出させる擋拌機が用いら れることが多い。図6にるつぼ内でのセット状態を示す。

駆動源として, エアモータ式と電気モー夕式が使用されて いる。前者は音が大きく騒音問題があるあのの, 大型でパ ワーがあり, また，アースの必要性がないのでフラックスを 使用する溶解工場でよく使われる。後者は小型で取扱いやす いが，フラックスの付着により吸湿すると感電の恐れがあり, 覆いなどの対策が必要である。フラックスレス溶解の作業場 


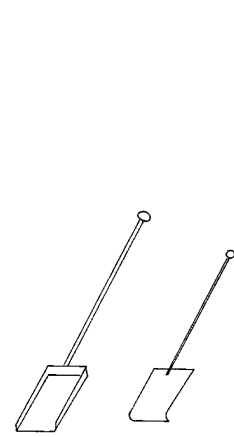

(a)

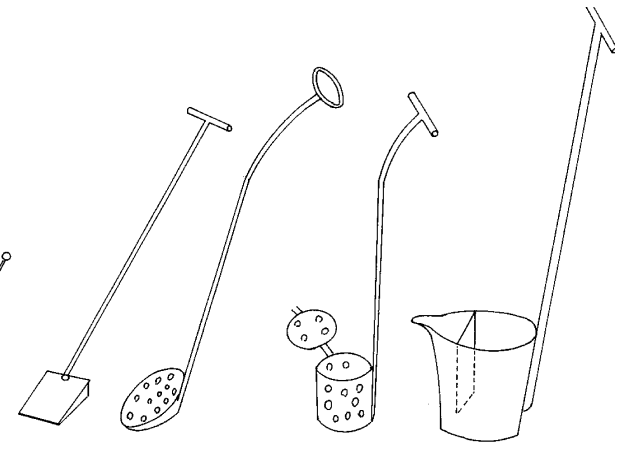

(e)

(f)
図 7 マグネシウム用溶解鋳造治工具類

（a）フラックス散布，（b）湯面滓，フラックス除去， （c）るつぼ内壁滓落し，（d）スラッジ除去，（e）ホ スホライザ, (f) スリット付ひしゃく

では後者が一般的である。撹拌による溶湯表面の乱れを少な くするように擋拌速度, るつぼ直径に対する回転羽根の大き さと形状を選定する。また, 回転子からの導入ガス量とガス 泡サイズならびに溶湯全体への噴出法などを検討して脱ガス 効率を向上させる。

（6）合金成分添加容器, 汲みひしゃくその他工具類 : 合金 成分はホスホライザに入れ溶湯中に保持しながら溶解し, 添 加率を安定させる。溶湯の柄杓による手動汲出しでは, じゃ ま板付を使用し, 滓などの混入を防止する。溶湯表面上の滓 の除去具などの治具とともに図 7 に形状例を示す。

\section{1 溶解作業}

$\mathrm{Mg}$ の溶解作業ではメタルの酸化を抑え, 不純物が混入し ないように配慮する。さらに酸化ロスをできるだけ少なくす るよう作業する。以下に, 溶解作業時に留意すべきことを記 す。

\section{（1）酸化防止}

溶融したマグネシウムは大気中の酸素と反応して着火・燃 焼し, 白色の酸化物 $\mathrm{MgO}$ を生成する。空気中の湿気（水分） は酸化反応を加速させる。静止状態の湯面では表面皮膜があ るので反応は局部に限られるが，撹拌などにより湯面を乱す ことによって着火面積は急速に拡大する。

(反応) : $\mathrm{Mg}+1 / 2 \mathrm{O}_{2} \rightarrow \mathrm{MgO}$ ；

$$
\mathrm{Mg}+\mathrm{H}_{2} \mathrm{O} \rightarrow \mathrm{MgO}\left(/ \mathrm{Mg}(\mathrm{OH})_{2}\right)+\mathrm{H}_{2}
$$

（2）酸化防止：フラックス ; 保護ガス

原料の加熱, 溶解工程でのメ夕ル酸化を少なくするために, フラックスによるカバーリング，保護ガス雾囲気による湯面 保護が適用される。ただし, フラックスの残留はトラブルの 原因になる。表 4 に酸化口スの発生する原因と対策例を工程 別に示した。

(3) 不純物混入

シリカ $\left(\mathrm{SiO}_{2}\right)$ 成分を含有する断熱材（特にファイバ状の シリカを圧縮成形し，バルク状にしたもの）は $\mathrm{Mg}$ 溶湯に接 触すると, 容易に発熱しながら反応して不純物のけい素 $(\mathrm{Si})$ が増加する。

(反応) : $\mathrm{SiO}_{2}+2 \mathrm{Mg} \rightarrow 2 \mathrm{MgO}+\mathrm{Si}$

(4) 不純物混入
るつぼ内壁などに生じた酸化鉄が溶湯中へ落下・蓄積する 之, 不純物 ( Fe) の含有量が増える。るつぼ内壁の異物除 去, 定期的な炉外における水洗クリーニングが重要である。 るつぼの溶融アルミニウムめっき処理はるつぼ内壁の酸化を 低減する効果がある。ただし，ジルコニウム（Zr) 含有合金 では $\mathrm{Al}-\mathrm{Zr}$ 化合物が生成するので使用上の注意が必要である。

(反応) : $\mathrm{Mg}+1 / 3 \mathrm{Fe}_{2} \mathrm{O}_{3} \rightarrow \mathrm{MgO}+2 / 3 \mathrm{Fe}$ ；

$\mathrm{xFe}+\mathrm{yAl} \rightarrow \mathrm{Fe}_{\mathrm{x}} \mathrm{Al}_{\mathrm{y}}$ （溶融アルミニウムめっき処理層）

（5）塗型剂

滑らかな外観表面の鋳塊を得るために，鋳型には断熱性の ある塗型剤（例えば，タルク $20+$ ほう酸 $1+$ 松やに 2 の水溶 液）を加熱・塗布し, 吸湿させないように保温しておく。酸 化鉄, 異物の落下 · 付着を防止し, 鋳型を常に清浄に保持す る。

（6）溶湯の着火・燃焼のリスク

$\mathrm{Mg}$ 合金の溶解作業において, 溶湯の酸化・燃焼は共晶温 度または固相線温度以上の温度で始まる。AZ91 合金では約 $430^{\circ} \mathrm{C}$ である。燃焼が始まると局部的に温度が上昇し, 加速 度的に酸化燃焼が進行する。さらに, るつぼ内への空気の侵 入によって酸素供給が継続されることや, 溶湯の対流により溶 湯表面の酸化膜が破れると, さらに酸化・燃焼が持続する。

したがって, 防燃, 酸化防止法としては,

・溶解速度を速めて溶解時間を短縮する, 例えば, 熱供給能 力の大きい炉を使用する

- 固形 $\mathrm{Mg}$, 小さい形状物は溶融 $\mathrm{Mg}$ 中に強制的に押込み, 溶解速度を速める

・るつぼ蓋をセットし，溶湯表面と空気の接触機会を少なく する

・るつぼ直径を小さく（深さの $1 / 2$ 以下）し, 露出する溶湯 表面積を小さくする

・溶湯の保持中はるつぼ下部の温度を低めにして対流を抑え, 湯面の酸化皮膜を破壊させない

・酸化防止用保護ガスなどを溶湯表面近くに供給し，上昇気 流による保護ガスの放散を防ぐ

・るつぼと蓋との密閉性を維持する

・減圧後不活性ガス雾囲気に置換して溶解する などの対策が採られている。

ただし, これらの対策は溶解コスト, 量産性, 設備コスト, 要求品質などを考慮して取捨選択して実施することが必要で ある。図 8 には燃焼しやすい $\mathrm{Mg}$ ビレットの外削ドライ切削 粉（ダライコ）を, 後述のフラックスを使用する溶解・精錬 の様子を示す。るつぼ蓋があることにより酸素とダライコと の接触機会が抑制され，さらに，見かけ比重の軽いダライコ を傾斜設置型の擋拌機により溶湯中に強制的に押込み溶解す ることで, 燃焼防止のためのフラックス使用量を抑え, 高い 溶解歩留まり（97\% 以上）でビレットとして再使用可能とし た。

(7) 注湯

密閉タイプの注湯機により溶湯を鋳型へ鋳造する。その他 保護ガスでカバーしながら炉から傾注する方法, あるいは汲 みひしゃくなどが利用される。 


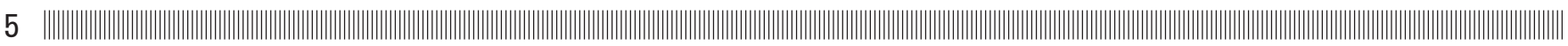

表 4 溶解時のメタルロス

\begin{tabular}{|c|c|c|}
\hline $\begin{array}{l}\text { メタルロスの } \\
\text { 発生時期 }\end{array}$ & 要 因 & 対 策 \\
\hline \multirow{10}{*}{$\begin{array}{c}\text { 1)溶け落ち前の } \\
\text { 酸化による } \\
\text { メタルロス }\end{array}$} & 1. チャージ材料の比表面積 & a. 小さい形状品の別途添加 \\
\hline & 2. 材料の付着水分 & b. 予熱温度 $\times$ 時間の適正化 \\
\hline & 3. 空気中の湿度管理 & c. 脱湿環境, 風通し環境 \\
\hline & \multirow[t]{3}{*}{ 4. 過大な材料装填空面積 } & d. るつぼカバーの二重空 ; 開閉時間の短縮 \\
\hline & & e. るつぼ内へのエア進入防止 \\
\hline & & $\begin{array}{l}\text { f. 原料装填面積を小さくするシュー夕を設置, 速やかに溶湯 } \\
\text { に浴解 }\end{array}$ \\
\hline & \multirow[t]{3}{*}{ 5. 溶融メタルの露出面積 } & g. 溶湯の露出表面積の小さい深鍋タイプ利用 \\
\hline & & h. 湯面近傍への保護ガスチャージ \\
\hline & & i. メタル湯面保護ガスの放散防止じゃま板設置 \\
\hline & 6. 材料の溶解速度 & j. 熱源を増やす：バーナ本数を増やす；擋拌 \\
\hline \multirow{6}{*}{$\begin{array}{l}\text { (2)溶解した後の } \\
\text { 酸化による } \\
\text { メタルロス }\end{array}$} & 7. 雰囲気ガスの対流 & k. 内壁部に中間カバーをセット \\
\hline & 8. 溶湯対流と不均一温度 & m. じゃま板等をセットして湯面を静止・安定化 \\
\hline & \multirow{3}{*}{$\begin{array}{l}\text { 9. 不適切な合金添加条件（温度, 擋拌機, 湯面の動き } \\
\text { 抑制, 材料の大きさなど） }\end{array}$} & n. 合金添加具 : フォスフォライザの利用 \\
\hline & & o. 高温保持時間の短縮 \\
\hline & & p. 湯面近傍への保護ガスパージ \\
\hline & 10. 合金化終了後目的温度まで緩慢な降下 & q. 炉底温度を下げ脱 Fe 促進 ; 強制空冷 \\
\hline \multirow{4}{*}{$\begin{array}{l}\text { (3)溶解滓の } \\
\text { 分離除去時の } \\
\text { メタルロス }\end{array}$} & \multirow[t]{2}{*}{ 11. 湯面酸化皮膜に付着随伴して持ち出されるメタル } & r. 摚拌時の酸化皮膜発生量低減 \\
\hline & & s. メタルのホールディング時間の短縮 \\
\hline & \multirow{2}{*}{$\begin{array}{l}\text { 12. るつぼ底部に沈んだ酸化物, 金属間化合物, } \\
\text { フラックスに随伴して持ち出されるメタル }\end{array}$} & t. 溶解初期 中期におけるメタル酸化防止 \\
\hline & & u. チャージ原料の清浄管理 \\
\hline
\end{tabular}

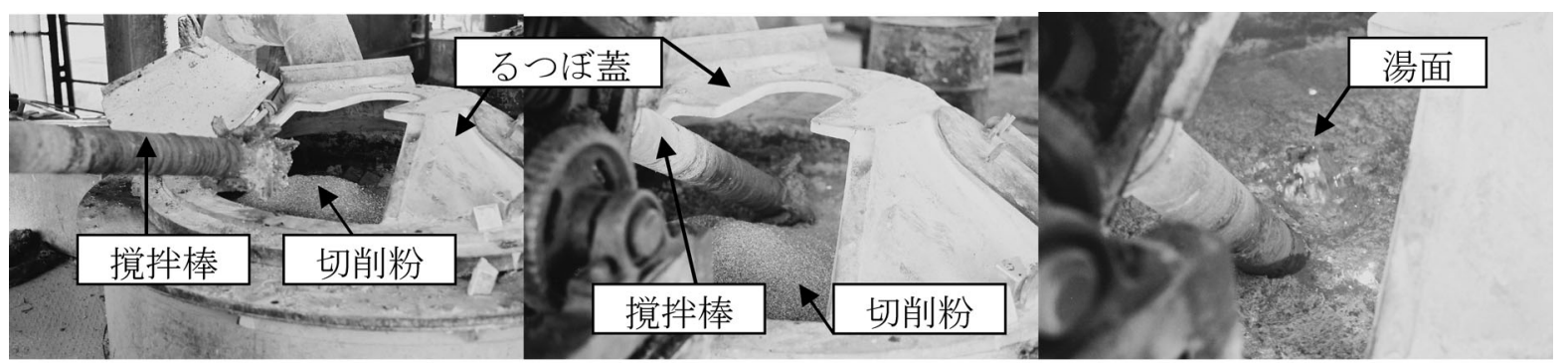

1. 切粉の湯面上装填と炉蓋

2. 切粉の溶湯内押込とゆるい撹挥

3. 撹挥とフラックス精錬

図 8 マグネシウム合金切削粉のフラックス精錬・撹挥の様子

\section{4. 溶解・精錬用フラックス (溶剂) ${ }^{1), 6,7)}$}

$\mathrm{Mg}$ および $\mathrm{Mg}$ 合金を溶解・精製する場合，一般にフラッ クスを用いることが多い。溶解歩留まりを向上させ介在物の 少ない清浄な溶湯を得るために, フラックスの機能を理解し
て使用しなければならない。

フラックスは通常次の二つの機能を持っている。

（1）酸化防止作用：溶湯表面と空気とを遮断して溶湯の酸 化・燃焼を防ぐ。

（2）精錬作用：原料と溶湯中の酸化物，窒化物などの不純 
|||||||||||||||||||||||||||||||||||||||||||||||||||||||||||||||||||||||||||||||||||||||||||||||||||||||||||||||||||||||||||||||||||||||||||||||||||||||||||||||||||||||||||||||||||||||||||||||||||||||||||||||||||||||||||||||||||||||||||||||||||||||||||||||||||||||||| 5

表 $5 \mathrm{Mg}$ フラックス組成と特徵

\begin{tabular}{|c|c|c|c|c|c|c|c|c|c|c|}
\hline 分類 & $\mathrm{MgCl}_{2}$ & $\mathrm{KCl}$ & $\mathrm{NaCl}$ & $\mathrm{BaCl}_{2}$ & $\mathrm{CaCl}_{2}$ & $\mathrm{MgF}_{2}$ & $\mathrm{CaF}_{2}$ & $\mathrm{MgO}$ & 特徵 & 開発社番号 \\
\hline \multirow{5}{*}{ 溶解用（M） } & 34 & 55 & & 9 & & & 2 & & & Dow230, FM110 A \\
\hline & & 57 & & 12.5 & 28 & & 2.5 & & $\begin{array}{l}\text { 希土類元素 } \\
\text { 含有合金用 }\end{array}$ & Dow220, FM140 \\
\hline & \multicolumn{5}{|c|}{ (Dow310 と混合併用して使用, $\mathrm{Mn}$ 添加用フラックス) } & $\begin{array}{l}\mathrm{MnCl}_{2} \\
=76\end{array}$ & 13 & 11 & Mn 添加用 & Dow 320 \\
\hline & 50 & 24 & 24 & & & & 2 & & & FM110C \\
\hline & 10 & 20 & 30 & & 40 & & & & & MEL-MZ \\
\hline \multirow{2}{*}{$(\mathrm{M})+(\mathrm{R})$} & 48 & 20 & & 23 & & & 5 & 4 & $\begin{array}{l}\text { ダイカスト } \\
\text { 再生 }\end{array}$ & Dow234, SK432 \\
\hline & 29 & 37 & & 9 & & & 12 & 13 & & SK13 \\
\hline \multirow{5}{*}{ 精錬・カバー用 $(\mathrm{R})$} & 50 & 20 & & & & & 15 & 15 & & Dow310, FM130 \\
\hline & 34 & 7 & 10 & & 15 & & 21 & 13 & & MEL-E \\
\hline & & & 8 & 37 & 19 & 25 & & & $\begin{array}{l}\text { 希土類元素 } \\
\text { 含有合金用 }\end{array}$ & 重質フラックス \\
\hline & & 23 & 15 & 37 & & 25 & & & $\begin{array}{l}\text { 希土類元素 } \\
\text { 含有合金用 }\end{array}$ & 重質フラックス \\
\hline & & 9 & 26 & & 41 & 24 & & & $\begin{array}{l}\text { 希土類元素 } \\
\text { 含有合金用 }\end{array}$ & 重質フラックス \\
\hline 防燃用散布粉末 & \multicolumn{8}{|c|}{$\mathrm{S}(25)+\mathrm{MgF}_{2}(75) ; \mathrm{S}(28)+\mathrm{H}_{3} \mathrm{BO}_{3}(62)+\mathrm{NH}_{4} \mathrm{BF}_{4}(10)$} & & 溶湯表面散布 \\
\hline
\end{tabular}

表 6 フラックス成分の物性值

\begin{tabular}{|c|c|c|c|c|c|}
\hline 分類 & 化合物 & 分子量 & 比重 & 融点 $\left({ }^{\circ} \mathrm{C}\right)$ & 沸点 $\left({ }^{\circ} \mathrm{C}\right)$ \\
\hline \multirow{6}{*}{ 塩化物 } & $\mathrm{MgCl}_{2}$ & 95.22 & 2.31 & 714 & 1418 \\
\hline & $\mathrm{KCl}$ & 74.56 & 1.98 & 772 & 1437 \\
\hline & $\mathrm{NaCl}$ & 58.45 & 2.16 & 801 & 1465 \\
\hline & $\mathrm{CaCl}_{2}$ & 110.9 & 2.15 & 772 & $>1600$ \\
\hline & $\mathrm{BaCl}_{2}$ & 208.27 & 3.1 & 960 & 1560 \\
\hline & $\mathrm{MnCl}_{2}$ & 124.84 & 2.98 & 650 & 1190 \\
\hline \multirow{5}{*}{$\begin{array}{c}\text { ふっっ化物, } \\
\text { 酸化物 } \\
\text { ほか }\end{array}$} & $\mathrm{MgF}_{2}$ & 62.28 & 3.15 & 1263 & 2332 \\
\hline & $\mathrm{CaF}_{2}$ & 78.08 & 3.18 & 1402 & 2500 \\
\hline & $\mathrm{NH}_{4} \mathrm{BF}_{4}$ & 104.84 & 1.87 & 238 & 分解 \\
\hline & $\mathrm{MgO}$ & 40.3 & 3.65 & 2825 & 3600 \\
\hline & $\mathrm{S}$ & 32.06 & 1.96 & 113 & 445 \\
\hline
\end{tabular}

物を吸収・沈降させ溶湯から分離する。

$\mathrm{Mg}$ および $\mathrm{Mg}$ 合金の溶解・精錬用フラックスの組成例を 表 5 に，またフラックス成分の物性值を表 6 に示す。フラッ クスは一般に塩化マグネシウム $\left(\mathrm{MgCl}_{2}\right)$ を主成分とし，ア ルカリ金属とアルカリ土類金属の塩化物, ふっ化物, 酸化物 の混合塩である。

$\mathrm{MgCl}_{2}$ は酸化物（ $\mathrm{MgO} ）$ や窒化物を吸収する作用之着火防 止効果が大きい。その他の塩化物は主に混合塩の溶融温度を
下げ，流動性を増す効果，あるいは表面張力を溶湯よりあ小 さくすることで被覆作用を与える。また, 塩化バリウム $\left(\mathrm{BaCl}_{2}\right)$ や塩化カルシウム $\left(\mathrm{CaCl}_{2}\right)$ は比重が大きいので滓の 分離・沈降を速める効果をもつ。

さらに，ふっ化マグネシウム $\left(\mathrm{MgF}_{2}\right)$, ふっ化カルシウム $\left(\mathrm{CaF}_{2}\right)$ ，酸化マグネシウム（MgO）は融点が高く，フラック スに粘調性や固化凝集性を与え, 残留フラックスを溶湯から 分離しやすくする。

（1）溶解用フラックス（表中で（M）表示）と呼ばれるも のは非常に流動性があり, したがって溶湯表面を被覆する作 用があるので酸化防止に有効である。当フラックスは精錬作 用むあるが流動性がよすぎるため溶湯との分離が難しく, 鋳 造時に鋳塊あるいは鋳物に混入する危険がある。

（2）精錬用フラックス（表中（R）表示）と呼ばれるむの は，溶解用フラックスに $\mathrm{MgF}_{2}, \mathrm{CaF}_{2}, \mathrm{MgO}$ などの粘調剤を 多量に添加することにより, フラックス自体に固化性を持た せたもので, 溶湯との分離性に優れている。溶湯に散布して 擋拌すると, 初めはある程度流動性を持ち, やがて溶湯中の 酸化物, 酸化皮膜, 窒化物, 滓, さらに残留している溶解用 フラックスを吸収して沈降する。

同時に溶湯の酸化を防ぐ。注湯作業時には容易に分離除去 できるのでフラックスの混入のリスクが低い。なお，表中で $(\mathrm{M}+\mathrm{R})$ 表示フラックスは（M）と（R）の中間的作用をも つ。 
（3）特殊用途フラックス（表中で希土類元素含有合金用と 表示）は，例えば合金成分中に金属カルシウム（Ca），金属 ストロンチウム $(\mathrm{Sr})$, 希土類元素のセリウム $(\mathrm{Ce})$, ランタ ン $(\mathrm{La})$ ，ネオジウム $(\mathrm{Nd})$, プラセオジウム $(\mathrm{Pr})$ ，ガドリ ニウム $(\mathrm{Gd})$ ，あるいはイットリウム（Y）などを含有する合 金に使用する。これは, $\mathrm{MgCl}_{2}$ が塩化反応により前述の元素 歩留まりを低下させるためで, この種のフラックスは, $\mathrm{MgCl}_{2}$ の代わりに重質系成分 $\mathrm{CaCl}_{2}, \mathrm{BaCl}_{2}$ を含有するが, 着火防止 性はやや劣る。

（4）フラックスの保管，使用上の注意としては，塩化物は 吸湿性が強いので, 密閉容器に保管し, 必要量を使用する。 吸湿したフラックスは性能が劣化し, $\mathrm{Mg}$ 溶湯中に水素ガス を増やす恐机がある。

\section{5. 合金化}

純 $\mathrm{Mg}$ に各種合金成分を添加して目的の合金を調製する場 合, 以下に示すインゴット，母合金あるいは化合物で添加す る。添加の際の留意点屯同時に示す。

(1) $\mathrm{Mg}$ 地金は有害不純物 ( $\mathrm{Fe}, \mathrm{Ni}, \mathrm{Cu}, \mathrm{Si}, \mathrm{Sn}, \mathrm{Ca}, \mathrm{Na}, \mathrm{K}, \mathrm{Pb}$ など）が成分規格以下であること。

(2) アルミニウム（Al）地金は $99.9 \%$ 以上のものを使用す る。溶解は容易である。

(3) 亜鉛 $(\mathrm{Zn})$ 地金は $99.9 \%$ 以上の屯のを使用する。溶解 は容易である。

(4) マンガン (Mn) は $\mathrm{Al}-10 \% \mathrm{Mn}$ 母合金, $\mathrm{Al}$ 粉末と $\mathrm{Mn}$ 粉末混合体（A180+Mn20）をブリケット化したものが主に使 用され, 約 $700 \sim 720^{\circ} \mathrm{C}$ で添加可能である。金属 $\mathrm{Mn}$ 単体の破 砕片で添加する場合ああるが，溶解に要する時間が長くなる。 また，海外では塩化マンガンむ利用されている。

(5) ベリリウム（Be）は $\mathrm{Al}-2.5 \% \mathrm{Be}$ 母合金を使用する。

６）銀（Ag）は金属粉を溶湯内部で溶解する。

(7) カルシウム（Ca）は粒状体を溶湯から浮上させずに, 酸化防止ガス雾囲気下で溶かす。フラックスを使用する場合 は $\mathrm{MgCl}_{2}$ を含有しないタイプを使用する。

(8) 希土類元素（RE）は，金属 REを添加する場合は $720^{\circ} \mathrm{C}$ 以上の温度で溶解可能であるが溶解時間を要する。一 般に融点を下げるために $\mathrm{Mg}-20 \sim 30 \% \mathrm{RE}$ の母合金を使用す る。フラックスを使用する場合は $\mathrm{MgCl}_{2}$ を含有しないタイプ を使用する。

(9) ジルコニウム $(\mathrm{Zr})$ は $\mathrm{Mg}$ との母合金（例えば約 $\mathrm{Mg}$ $30 \%$ Zr の Zirmax ${ }^{\circledR}$ など）を使用する。添加温度は高く，約 $750 \sim 800^{\circ} \mathrm{C}$ である。添加作業はるつぼ底部を治具でゆっくり こすりながら溶かし込む操作で，パドリング (paddling) と いわれる。 $\mathrm{K}_{2} \mathrm{ZrF}_{6}-\mathrm{KCl}$ 混合塩を $\mathrm{Mg}$ 溶湯に添加する方法もあ るがコスト的に不利である。

\section{6. 脱ガス ${ }^{6}$}

$\mathrm{Mg}$ の溶解原料として細片, 薄肉材などを使用した場合は, 比表面積が大きいので表面酸化物, 水酸化物の総量が増え, 水素ガスが導入されるリスクが大きい。特に，切削剤や油な ごの付着した切粉あるいは，屋外保管により腐食した切削粉 を使用した場合は，精錬後の鋳塊表面部にガスふくれが生じ

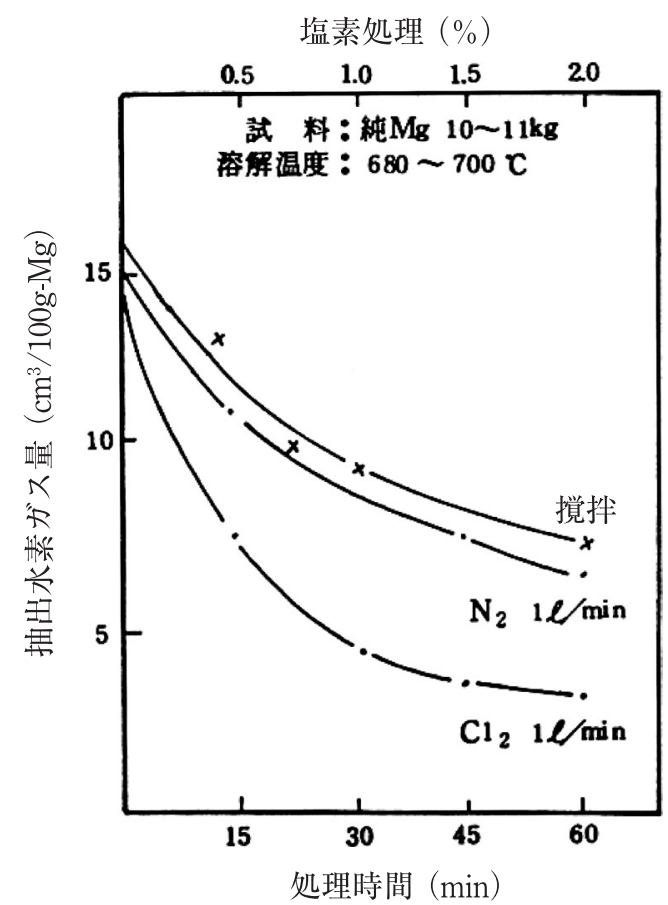

図 9 純マグネシウムの脱ガス試験

る場合があり，精錬・脱ガスの処理時間を延長する必要があ る。ふくれを発生した鋳造テストピースからの抽出ガス量は $20 \mathrm{~cm}^{3} / 100 \mathrm{~g}-\mathrm{Mg}$ 以上が認められる。溶解原料は腐食させない ようにし，室内で保管する必要がある。

図 9 に純 $\mathrm{Mg}$ （10 kg 溶解）のフラックス溶解における脱ガ ス試験の結果を示す。（a）擋拌作業,（b）[塩素 $\left(\mathrm{Cl}_{2}\right)$ ガス + 擋拌], (c) [窒素 $\left(\mathrm{N}_{2}\right)$ ガス + 擋拌] による効果を調べた 結果によると，脱ガス作用は（b）擋拌作業を行いながらの 塩素ガスバブリングが最も効果的であったが，(c) 撹拌作業 を行いながらの不活性ガスの吹込み，(a）単純擋拌作業も有 効であることを示している。実際の生産工場では微細なガス 気泡を擋拌羽根で溶湯中に破砕 ・分散させて, 水素ガスの除 去と酸化物の浮上分離を遂行し，同時にフラックスによって 酸化物を除滓することにより，効率よく脱ガスを行っている。 経験的にはガス量が $10 \mathrm{~cm}^{3} / 100 \mathrm{~g}-\mathrm{Mg}$ 以下では気孔はインゴッ ト中に発生しない。

\section{7. 品質 7),8)}

\section{1 不純物元素の管理}

$\mathrm{Mg}$ 合金地金および鋳造製品について，耐食性を低減する 不純物元素（Fe, $\mathrm{Ni}, \mathrm{Cu}, \mathrm{Si}$ など）の含有量は ASTM 規格によ り決められている。しかし, 不純物元素の中で, 現在工業的 に溶湯から除去できる不純物元素は Fe だけである。すなわ ち合金の調製時には $\mathrm{Mn}, \mathrm{Al}$ などを添加し, 金属間化合物 $\mathrm{Mn}-\mathrm{Fe}, \mathrm{Al}-\mathrm{Mn}-\mathrm{Fe}$ を生成させ, 溶湯温度を約 $650^{\circ} \mathrm{C}$ 以下に保 持することで溶湯底部に分離沈降させ，除去している。その 他の不純物は除去できない。

返り材を再生・利用する場合, 不純物の混入によって規格 外れの溶湯が生産される危険性がある。以下には AZ91D 合 金インゴット製造において, 外部から混入し得る異物例と原 
料 1 トン当たりの混入限界量を示すが，元の不純物含有量む 考慮しなければならない。

（1） Fe：鉄さび，アルミニウム材などとしての混入限界量 は $50 \mathrm{~g}(50 \mathrm{ppm})$ 未満

(2) Ni：ステンレス鋼，ニッケルメッキなどとしての混入 限界量は $10 \mathrm{~g}(10 \mathrm{ppm})$ 未満

(3) $\mathrm{Cu}$ : 亜鉛鋳物, アルミニウム鋳物, 電線などとしての 混入限界量は $150 \mathrm{~g}(150 \mathrm{ppm})$ 未満

(4) $\mathrm{Si}$ : 砂 $\left(\mathrm{SiO}_{2}\right)$, 離型剤, 研磨剂, 断熱剤, 塗料, アル ミニウムなどとしての混入限界量は $1.0 \mathrm{~kg}(1000 \mathrm{ppm})$ 未満

合金インゴット中の Mn 含有量について, Mn は合金の耐 食性を向上させる成分元素であり，不純物元素 Fe を低下さ せるための添加材でもあるが，Mn 含有量が多くなると溶湯 からのスラッジ発生量が増えることが知られている。また AM60B，AM50 A 合金などの規格では AZ91D 合金よりあ Mn 含有量が多いので, インゴット製造温度に比べダイカスト温 度が低い場合には，晶出した $\mathrm{Mn}$ や $\mathrm{Al}-\mathrm{Mn}$ 系金属間化合物が 再溶解せずに残り，ダイカスト鋳造製品中に大きな介在物之 して混入することがある。延性の要求される部品中に混入す ると破壊起点となるリスクがある。AM 系合金インゴットは $\mathrm{Fe}$ の許容規格を満足させながら, 適切な $\mathrm{Mn}$ 含有量であるこ と，拈よびインゴット鋳造温度とダイカスト温度に配慮する ことが必要である。

\section{2 塩化物污染}

$\mathrm{Mg}$ および $\mathrm{Mg}$ 合金インゴットの一次精錬工場，合金製造 工場および再生工場においては，塩化物系フラックスを使用 して溶解・精錬し, 溶湯中不純物, 酸化物, 酸化皮膜なよ゙を 吸着 - 分離する。油付着の原料, 微細な酸化物や酸化皮膜量 の多い原料を溶解する場合は, 溶湯の粘性の上昇, あるい は, 表面張力の低下により, 溶解・精錬工程において使用し たフラックスの溶湯からの分離が不完全となり，鋳造イン ゴット中に混入する可能性が増す。インゴット中に塩化物が 残留すると，インゴットの腐食クレームひいては最終鋳造製 品を腐食させるという問題を生じることがある。

塩化物の混入防止のための作業基準の見直し例としては, フラックス組成と使用量, 精錬・擋拌条件, 溶湯温度と保持 時間, 鋳造方法と鋳造条件など, 設備の改善例では汲出しポ ンプの構造と配置, 擋拌機形状, 炉の加熱条件などの対策が なされるが, 同時に, 鋳造インゴットの確実な検査などの対 策を実施する。

図 10 は合金インゴットの製造ラインにおいて，インゴッ 卜中の塩素含有量を 1 年間追跡した例を示す。平均值は $9 \mathrm{ppm}$ であるあのの，22ppm（Max）に急増した時期も見られ たが, 溶湯温度の均一化と保持時間の適正化, あるいはポン プによる溶湯の汲出し深さの变更などを対策した結果，その 後の平均值は $5 \mathrm{ppm}$, 最大值 $10 \mathrm{ppm}$ に改善された。なお, イ ンゴット中の塩素含有量については規格がないが，商業上は 一般的には $50 \mathrm{ppm}$ 以下が適用されている。

\section{3 インゴットの保管}

$\mathrm{Mg}$ および $\mathrm{Mg}$ 合金インゴットの生産者は，湿度の少ない 通風のよい倉庫内にインゴットを保管し，先入れ・先出しを 基本とする。一般的に固体のマグネシウムは常温では安定で

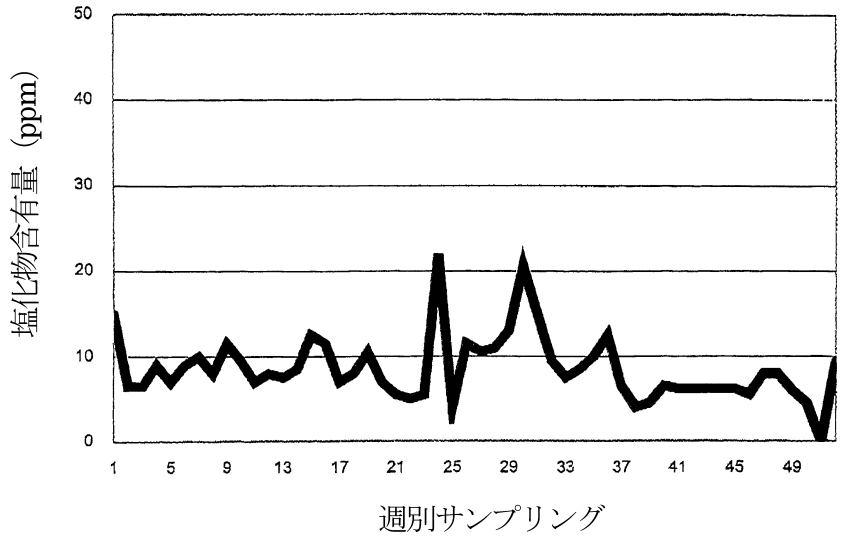

図 10 AZ91D 合金インゴット中の塩素含有量の推移調 査例（平均值 $9 \mathrm{ppm}$, 最大值 $22 \mathrm{ppm}$, 最小值

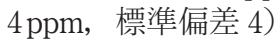

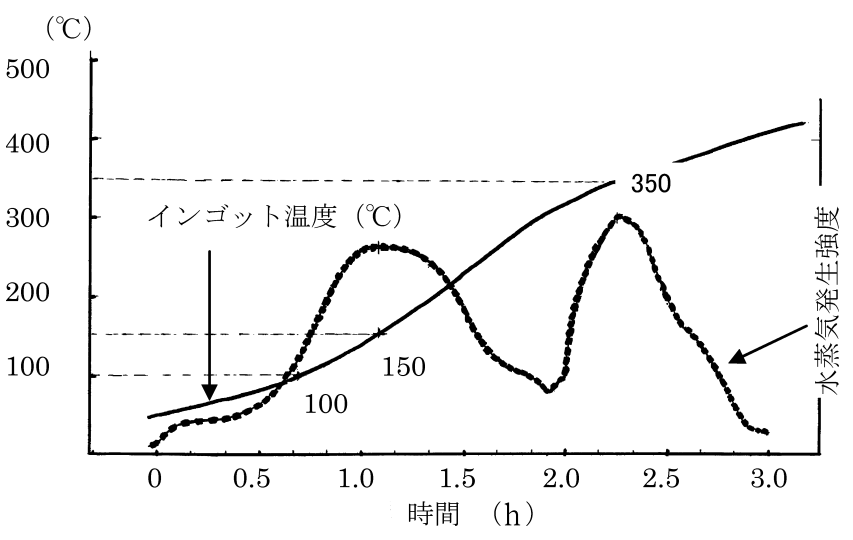

図 11 腐食インゴットの加熱温度と水蒸気発生の関係

あるが，湿度が高い場合大気中で徐々に酸化変色し，亜酸化 物が生じると, 灰色から黒色の皮膜が生成する。黒鉛が生 成・付着したもの之勘違いすることがある。表面にはその他, 水酸化物, 炭酸塩なども生じる。純 $\mathrm{Mg}$ は $\mathrm{AZ}$ 系マグネシウ 么合金に比べ变色が少ない。

(反応) : $\mathrm{Mg}+1 / 2 \mathrm{O}_{2} \rightarrow \mathrm{MgO}$ ；

$$
\begin{aligned}
& 2 \mathrm{Mg}+(1-\mathrm{x}) \mathrm{O}_{2} \rightarrow 2 \mathrm{MgO}_{(1-\mathrm{x})} ; \\
& 2 \mathrm{Mg}+3 \mathrm{H}_{2} \mathrm{O} \rightarrow \mathrm{Mg}(\mathrm{OH})_{2}(/ \mathrm{MgO})+2 \mathrm{H}_{2}
\end{aligned}
$$

$\mathrm{Mg}$ インゴットの外観に関する苦情, クレームは品質管理 上重要な課題である。

部分腐食したインゴットの場合, 表面には付着水分および 水酸化マグネシウムが生成しており, 加熱によって付着水分 および水酸化物の分解による水蒸気が放出する。図 11 には 一部腐食が認められるインゴットについて, 加熱温度と水蒸 気発生との関係を調べた結果を示す。約 $100 \sim 150^{\circ} \mathrm{C}$ 付近で付 着水分の放出が見られ, $300 \sim 350^{\circ} \mathrm{C}$ 付近では腐食生成物の水 酸化物から, 分解水の放出が起こっている。

ダイカスト工程においてインゴットを溶湯中に投入したと きに，気泡が溶湯表面に発生すると，溶湯表面には酸化膜が 生成し, 集積した場合はドロス化し, 沈降するとスラッジと してメタルロスの原因となる。表面の清浄なインゴットの予 熱温度は，付着水分を蒸発させるために $150^{\circ} \mathrm{C}$ 以上で十分で あるが， $\mathrm{Mg}(\mathrm{OH})_{2}$ などの腐食物が生成しているインゴットの 


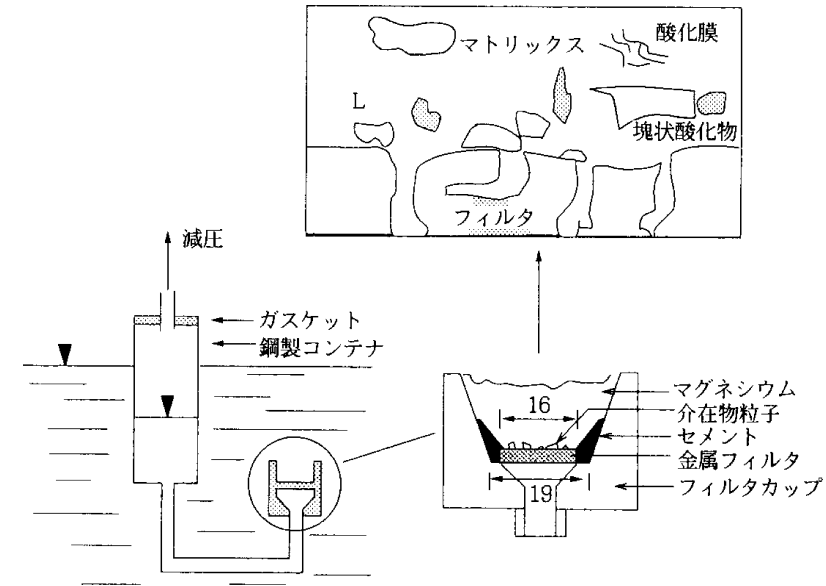

図 12 溶湯中介在物のろ過フィルタによる評価法

場合は，予熱温度は約 $350^{\circ} \mathrm{C}$ が適切である。

(分解反応) $: \mathrm{Mg}(\mathrm{OH})_{2} \rightarrow \mathrm{MgO}+\mathrm{H}_{2} \mathrm{O}$

\section{4 マグネシウム中の介在物評価法 ${ }^{8)}$}

$\mathrm{Mg}$ 中の介在物は主に酸化物 - 窒化物, 酸化皮膜 - ふっっ化 物皮膜, 金属間化合物および塩化物などがある。現在, リサ イクル材の評価に実用され，信頼性のあるデータが Norsk Hydro 社および Dow 社から発表されているが, 介在物の評価 技術がやや複雑で, デー夕の処理時間を要する。前者は溶湯 を通過させたフィルタを切断し，フィルタにトラップされた 介在物の有無, 組成, ならびに量を顕微鏡観察により評価す る方法である。2 ポット炉におけるスクラップの再生プロセ スについて, 溶湯中の介在物量の変化を調べ, プロセスの有 効性を示している。後者は鋳造サンプル断面の反射率を調べ, 介在物量を評価する方法である。図 12 には溶湯中の介在物 のろ過フィルタによる評価法を示す。

自動車用重要保安部品などは延性が重視されるので, 介在 物量の抑制は重要であり, 展伸材や航空機用高級鋳物への適 用時も同様である。現場で利用可能で信頼性のある評価法の 確立が待たれる。

\section{8. 酸化防止用保護ガス ${ }^{9), 10}$}

マグネシウム溶解鋳造工程でフラックス精錬法が適用され
る場合であっても, 静置・鋳造工程では保護ガスが使用され る。塩化物混入のリスクは絶対的に避けなければならないた めである。保護ガスの最近の動向, 特に代替ガスについては, すでに本講座の「マグネシウム合金の取扱いと安全対策」（軽 金属, Vol. 59, No. 3 (2009), pp. 154-165）の項に詳述した。 保護ガスは高価であり, 温暖化ガス排出量の削減の必要性か らも使用量は抑制しなければならない。保護ガスの使用量削 減では次のような, きめ細かい配慮の積み重㸚が重要である。

(1) マスフローメータ式ガス濃度制御計を使用（低濃度域 で有効）

(2) ガス濃度を下げる（ $\mathrm{SF}_{6}$ ガスの場合密閉炉では 0.10 $\mathrm{vol} \%$ )

(3) ガス流速を速くして目標湯面に確実に到達させる

(4) 炉からのガスリークを厳重に抑制する

(5) 蓋の空開閉などの作業に伴うガスの逸散を防止する

（6)できる限り溶湯表面積が小さくなるように設計する

（7）溶湯表面の乱れを抑える

(8) 溶湯の対流を抑えて溶湯表面上の保護皮膜を安定化す る

(9) 雾囲気中の水分を $0.080 \mathrm{vol} \%$ （露点 $-16^{\circ} \mathrm{C}$ ）以下に抑 制し,メタルの着火性を抑える

などが挙げられる。

\section{参 考 文 献}

1) E. F. Emley: Principles of Magnesium Technology (Pergamon Press 1966).

2) US-Magnesium 社 技術資料.

3）小松龍造：マグネシウム製錬，マグネシウム便覧，軽金属協会， (1975).

4）日本マグネシウム協会 統計資料.

5) ASM: Metals Handbook vol. 8.

6）伊藤 茂：マグネシウムの溶解，マグネシウムマニュアル 1983 , 1984, マグネシウム委員会, (1983), (1984).

7） Magnesium Elektron 社 技術資料カタログ.

8）伊藤 茂：マグネシウムのリサイクルの現状, 軽金属, 33 (2003), 272.

9）伊藤 茂：マグネシウム基礎講座 1, 軽金属, 59（2009）, 154-165.

10） 日本アルミニウム協会, 日本マグネシウム協会：NEDO 報告書 バーコード 100008451 (2005). 


\section{問 題}

マグネシウムの合金成分として Ca，Sr，希土類金属（RE）を添加・溶製するとき，ならびに回収再生するときに塩化 マグネシウムを含まない（または極少量しか含有しない）フラックス（溶剤）を使用することが推奨されている。その理 由を述べよ。

\section{回答}

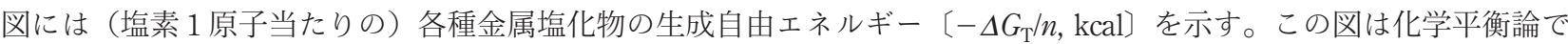
は“生成自由エネルギーが大きいほど，エネルギー的に安定である”ことを意味し，エネルギー的に安定な状態の化合物 に変化する。したがって, 反応が進行し得ることを意味して いる。

例として「金属 $\mathrm{Mg}$ が塩化反応によって $\mathrm{MgCl}_{2}$ （塩化マグ ネシウム）に变化する反応と，金属 $\mathrm{Ca}$ が塩化反応で $\mathrm{CaCl}_{2}$ （塩化カルシウム）に变化する反応の生成自由エネルギーを比 較してみる。

それぞれの反応と生成自由エネルギーの $1000 \mathrm{~K}$ での值を図 から求める。

反応 (1) $: 1 / 2 \mathrm{Ca}+\mathrm{Cl} \rightarrow 1 / 2 \mathrm{CaCl}_{2}: \Delta G(1)=$ 約 $-76 \mathrm{kcal}$

反応 $(2): 1 / 2 \mathrm{Mg}+\mathrm{Cl} \rightarrow 1 / 2 \mathrm{MgCl}_{2}: \Delta G(2)=$ 約 $-58 \mathrm{kcal}$

反応式同士を差引き，(3）とすると反応式は次のようになる。

$1 / 2 \mathrm{Ca}-1 / 2 \mathrm{Mg}=1 / 2 \mathrm{CaCl}_{2}-1 / 2 \mathrm{MgCl}_{2}: \Delta G=(\Delta G(1)-\Delta G(2))$

$\therefore(3): 1 / 2 \mathrm{Ca}+1 / 2 \mathrm{MgCl}_{2}$

$$
=1 / 2 \mathrm{CaCl}_{2}+1 / 2 \mathrm{Mg}: \Delta G_{1000}=-76+58=-18 \mathrm{kcal}
$$

よって反応（3）が進行し得る。（ただし，どのくらい，速や かに進行するかは別である。）

また，平衡定数 $K$ は次のようになる。

$$
\begin{aligned}
& \log _{10} K=\frac{-\Delta G_{1000}}{4.575 T} \\
& \text { よって } \log _{10} K=-18,000 / 4,575=-3.934 \quad \therefore K=0.0001 \\
& K=\frac{a_{\mathrm{Ca}} \cdot a_{\mathrm{MgCl}_{2}}}{a_{\mathrm{Mg}} \cdot a_{\mathrm{CaCl}_{2}}}
\end{aligned}
$$

分母は 1 に近似であるので, 合金中の $\mathrm{Ca}$ の活量 $a_{\mathrm{Ca}}$ は非常に 小さい值にならざるを得ず，したがって Ca 濃度む小さい。

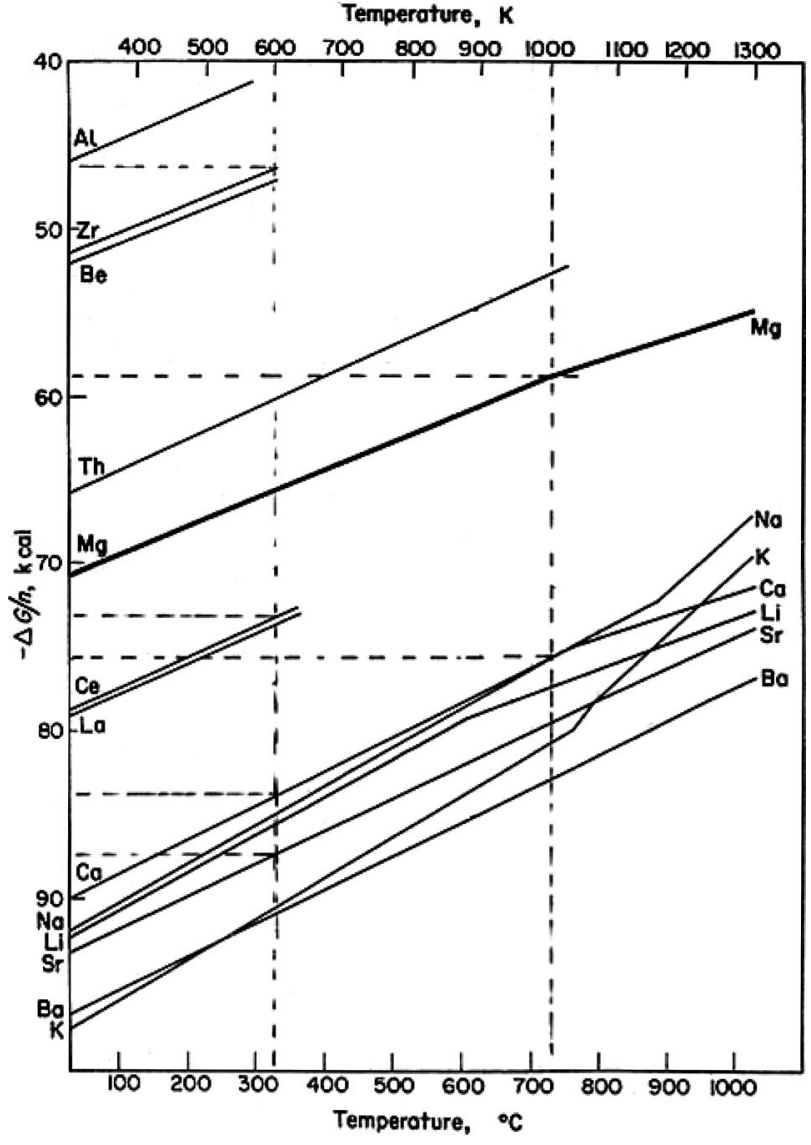

図＼cjkstart塩化物の生成自由エネルギーと温度の関係 ${ }^{1)}$

同様に $\mathrm{Sr}$ や希土類金属むフラックス精錬により成分がロスする。ただし溶解・擋拌時間と処理温度などの条件により, ロス率は異なる。なお，ピジョン法で $\mathrm{Mg}$ を製錬した場合， $\mathrm{Ca}$ あ凝縮することがあるが， $\mathrm{MgCl}_{2}$ リッチのフラックスで十 分溶解，撹拌精錬することにより脱 $\mathrm{Ca}$ ができた。 